\title{
Impact of Claim Settlement on Sales of Life Insurance policies - A Case Study of LIC of India
}

\author{
Rajesh K. Yadav \\ Department of Management, RKDF College of Engineering, Bhopal (M.P.), India \\ E-mail address: drrajeshkyadav@yahoo.com
}

\begin{abstract}
Claim settlement is one of the most important parts of the life insurance services. Person who is holding or planning for the life insurance will always want to have prompt claim settlement. For any insurance company sales of insurance policies is the biggest source of revenue and if claim are not properly settled then it will affect its sales. The study is based on the secondary data collected from IRDA annual report and it shows that LIC of India continue to grow due to its prompt claim settlement, highest insurance premium collections and highest number of policies sold.
\end{abstract}

Keywords: Claim settlement; Sales; Life Insurance; LIC of India

\section{INTRODUCTION}

Insurance is a protection against economical loss arising due to an unexpected event. In any type of insurance coverage claim settlement plays very important part. Claims settlement is an integral part of the insurance business. Growth in insurance business is depended on the people, the customers and consumers of service. Insurance is an arrangement by which the losses incurred by a small number of insured are divided over many exposed to same type of risks. Insurance contract is a contract by which one party called the insurer promises to save the other party, the insured on payment of consideration known as the premium. A right of insured to receive the amount secured under the policy of insurance contract promised by insurer is called claim. Claims can be maturity claims arise because of survival up to the end of the policy term i.e. to the date of maturity, survival benefits due to survival up to a specified period during the term, death claims arise due to death of the life assured during the term. Policy holders or nominees must first file an insurance claim before any money can be provided. An insurance claim is provided by an insurance company. The insurance company may or may not approve the claim, based on their own assessment of the condition under which claim is made. Individuals pays regular or sometime single premium for their insurance coverage. Most of the time, these premiums are used to settle another person's insurance claim or to build up the available assets of the insurance company.

When claims are filed, the insured has to observe the settled rules and procedures and the insurer has also to reciprocate in a similar manner by undertaking appropriate steps for speedy disposal of claims. It is true that claims settlement is complex in nature, but it is the driving force to plant confidence in the hearts of people, in general and beneficiaries in specific. 
Insurance claim is a right of insured under a contract of insurance. The insurer promises to save the insured or nominees/assignees of the insured on happening of event or risk insured. Disputes crop up in the payment of claim when the insurer and the insured understand the process of claims payment in a different way. It is obvious for the insurance company to protect and guard the interests of the policyholders. An insurance claim is the only way to officially apply for benefits under an insurance policy, but until the insurance company has assessed the situation it will remain only a claim, not a pay-out. For any life insurance company, sales of life insurance policies are major source of revenue and their prime motive for business. Since today business activities are interconnected, services related to claim settlement have impact on sales of life insurance policies to great extent.

\section{LIFE INSURANCE IN INDIA}

In the year 1818 business of life insurance in India in its existing form started with the establishment of the Oriental Life Insurance Company in Kolkata. It was started by Mr Bipin Behari Dasgupta and Europeans living in India were their primary customers. The first native insurance provider in India was formed in 1870 with the name Bombay Mutual Life Assurance Society. As on till date there are total 23 Life Insurance Companies in India. Life Insurance Corporation of India, ICICI Prudential Life Insurance Company, Bajaj Allianz Life Insurance Company, and HDFC Standard Life Insurance Company Etc., are the few names of Public sector and Private sector companies.

In life insurance there are two important parties to the contract, the policy holder and the insurer. Basically life insurance policies are legal contract between the policy holder and the insurer, terms and conditions are to be describing on it. It is a contract between the policy holder and the insurer to pay nominee a sum of money on the occurrence of the insured person's death or in the case of maturity of the policy, policy holder will receives whatever amount he has deposited as premium plus bonus on it. In return policy holder agrees to pay fix amount of premium on regular basis or in lump sum (one time premium payment) to the insurer.

Life insurance is mainly taken for two objectives, first is for risk coverage and second is for the investment objective.

i) Risk coverage: - Lump sum payment is provided if specific event occurred.

ii) Investment: -Money is invested with a motive of getting greater return.

Following are the types of the Life Insurance:

i) Term Life Insurance

ii) Whole Life Insurance

iii) Endowment Life Insurance

iv) Money Back Life Insurance

v) Unit Linked Insurance Policies

\section{LIFE INSURANCE CORPORATION OF INDIA}

There are various types of risk in life which can be covered with the help of Life Insurance policies, for this purpose Life Insurance Corporation of India (LIC) was created on $1^{\text {st }}$ September 1956, after the parliament of India passed the Life Insurance Corporation act on 
the $19^{\text {th }}$ of June 1956. Till 2000 it enjoyed a monopoly status and better known as synonymous of Life Insurance. LIC of India is one of India's leading financial institutions, offering complete financial solutions that cover every sphere of life. Its customer base is approx. 23 crores which is the largest in terms of Insurance Company. LIC has hundred divisional offices and has established extensive training facilities at all levels. They have their own Management Development Institute, seven Zonal Training Centers and 35 Sales Training Centers. As on till date LIC's staff strength is of 1.24 Lakh employees and 2048 branches and over Eleven Lakh agents. It is the second biggest Real Estate Owner after Indian Railways. LIC of India is one of India's leading financial institutions, offering complete financial solutions that encompass every sphere of life. From commercial banking to stock broking to mutual funds to life insurance to investment banking, the group caters to the financials needs of individuals and corporate. It has been started with the objectives of spreading Life Insurance widely and in particular to the rural areas; to meet the various life insurance needs of the community that would arise in the changing social and economic environment. The LIC has a net of over Rs. 1,800 crores.

\section{1. Claims settlement process followed by LIC of India}

The LIC of India has laid emphasis on prompt settlement of death as well as maturity claims. Claims are normally paid however if found any fraudulent then it is referred to claim committee operating in zonal offices and central offices. The process for settlement of maturity and death claims is as follows as:

The death claim amount is payable in both conditions, when policy's premiums is paid up-to-date and where the death occurs within the days of grace. After receiving information regarding death of the Life Assured the Branch office required following things:

1. Claim form A - Claimant's Statement giving details of the deceased and the claimant.

2. Certified extract from Death Register

3. Documentary proof of age, if age is not admitted

4. Evidence of title to the deceased's estate if the policy is not nominated, assigned or issued under M.W.P. Act.

5. Original Policy Document

The following additional forms are required if death occurs within three years from the date of risk or from date of revival/reinstatement:

1. Claim Form B - Medical Attendant's Certificate to be completed by the Medical Attendant of the deceased during his/her last illness

2. Claim Form B1 - if the life assured received treatment in a hospital

3. Claim form B2 - to be completed by the Medical Attendant who treated the deceased life assured prior to his last illness.

4. Claim Form $\mathrm{C}$ - Certificate of Identity and burial or cremation to be completed and signed by a person of known character and responsibility

5. Claim form E - Certificate by Employer if the assured was employed person.

6. If death was due to accident or unnatural cause certified copies of the First Information Report (FIR), the Post-mortem report and Police Investigation Report. These additional forms are required at the time of investigation by the officials of the Corporation and to prove the genuineness of the claim. 


\section{In case of Maturity Claims:}

1. Amount is payable at the end of the policy period when it is Endowment type of Policies, At least two months before the due date of payment the Branch which provide services to the policy intimate the policyholder by sending a letter informing the date on which the policy amount is payable. Discharged form duly filled is requested in return from the policyholder along with the all policy document. After receiving documents postdated cheque is sent by post so as to reach the policyholder before the due date.

2. Plans like Money Back Policies give periodical amount to the policyholders if premium due under the policies are paid up to the anniversary due for Survival Benefit. In cases where amount payable is less than up to Rs.60,000/-, cheques are released without calling for the Discharge Receipt or Policy Document. However, in case of higher amounts discharge receipt or policy document is mandatory.

\section{2. Impact of Claim Settlement on Sales}

Sales of Life Insurance policies are the biggest source of revenue for life insurance companies. Impact of claim settlement on sales can be understand with claim settlement ratio and claim settlement process against total life insurance premium earned and number of policies sold. Assessing the claim settlement ratio is the most significant criteria in establishing the credibility of a life insurer. Put simply, claim settlement is the ratio of the number of claims settled to the total number of claims filed in a particular fiscal year. The claim settlement ratio of LIC is better than that of the private life insurance players. Settlement ratio of LIC has increased to 97.73 during the year 2012-2013 when compared to 97.42 percent during the previous year. The highest claim settlement ratio that LIC boasts of is primarily the reason, why it gets to enjoy the trust of the major chunk of the market.

\begin{tabular}{|c|c|c|c|c|}
\hline S.No. & Insurer & No. of Claim Filed & $\begin{array}{c}\text { No. of Claims } \\
\text { Paid }\end{array}$ & $\begin{array}{c}\text { Claim Settlement } \\
\text { Ratio }\end{array}$ \\
\hline $\mathbf{1}$ & LIC & $\mathbf{7 5 0 5 7 6}$ & $\mathbf{7 3 3 5 4 5}$ & $\mathbf{9 7 . 7 3}$ \\
\hline 2 & ICICI Prudential & 14928 & 14393 & 96.29 \\
\hline 3 & HDFC Standard & 6253 & 5988 & 95.76 \\
\hline 4 & Max Life & 9051 & 8531 & 94.25 \\
\hline 5 & SBI Life & 13426 & 12676 & 94.14 \\
\hline
\end{tabular}

*Source IRDA Annual Report 2012-2013.

\section{3. Total Life Insurance Premium Earned}

A major fraction of the premium earned by a life insurance company goes into the fund that is deployed to pay the insured when he/she files a claim. It becomes a measure of how financially sound an insurer is. Thus, the premium earned by an insurance company suggests whether or not, the life insurance company be able to fulfill its obligation of making up for the loss of the insured in case of an eventuality. 


\begin{tabular}{|c|c|c|}
\hline S.No. & Insurer & Total Life Insurance Premium Earned (in crores) \\
\hline $\mathbf{1}$ & LIC & $\mathbf{2 0 8 8 0 3 . 5 8}$ \\
\hline 2 & ICICI Prudential & 13538.24 \\
\hline 3 & HDFC Standard & 11322.68 \\
\hline 4 & SBI Life & 10450.03 \\
\hline 5 & Bajaj Allianz & 6892.70 \\
\hline
\end{tabular}

*Source IRDA Annual Report 2012-2013.

\section{4. Number of Policies Sold}

The number of policies that a life insurance company issues in a fiscal year is only a reflection of how well the company is performing in the market. As can be seen, the undisputed market leader is LIC.

\begin{tabular}{|c|c|c|}
\hline S.No. & Insurer & Total Individual Policies (New Business) \\
\hline $\mathbf{1}$ & LIC & $\mathbf{3 6 7 5 5 4 5 1}$ \\
\hline 2 & Bajaj Allianz & 1025739 \\
\hline 3 & ICICI Prudential & 959958 \\
\hline 4 & SBI Life & 888670 \\
\hline 5 & Reliance & 762532 \\
\hline
\end{tabular}

*Source IRDA Annual Report 2012-2013.

From the above it can be seen that LIC of India has better claim settlement ratio and predefine claim filing procedure which ultimate boost the total life insurance premium earned and number of policies sold.

\section{CONCLUSION}

Claim settlement is one of the most important parts of the life insurance services. For any insurance company sales of insurance policies is the biggest source of revenue and if claim are not properly settled then it will affect its sales. After the opening up of life insurance market, LIC of India still strongly holds major market due to prompt claim settlement, trust and adaptability to change with changing environment. The study shows that there is a positive relationship between Sales and Claim Settlement. Better Claim settlement leads to better sales figure and customer relation. LIC of India holds leading position in the life insurance market due to its better claim settlement process and ratio. 


\section{References}

[1] Barot Haresh, Patel Jayesh and Patel Sweta (2012): "Service Quality and Customer Satisfaction in Indian Insurance Industry", Prerana Journal of Management Thought and Practice, 4(2); 1-13.

[2] Chaudhary Sonika and Kiran Priti (2011): "Life Insurance Industry in India - Current Scenario", International Journal of Management \& Business Studies, 1(3); 146-150.

[3] Das Debabrata and Debnath Jasojit (2012): "Performance of Insurance Companies in India: A Comparison of Public and Private Insurers", The IUP Journal of Risk \& Insurance, 9(1); 7-26.

[4] Krishnan Bindu (2010): "Claims Management and Claims Settlements in Life Insurance", The Journal of Insurance Institute of India, XXXVI; 49-57.

[5] Kuhlemeyer Gregory A. and Allen Garth H. (1999): "Consumer Satisfaction With Life Insurance: A Benchmarking Survey", The Journal of the Association for Financial Counseling and Planning Education, 10(2); 35-48.

[6] Kutty Shashidharan (2010): "Indian Life Insurance - The Millennial Decade", The Journal of Insurance Institute of India, XXXVI; 15-45.

[7] Mittal Alok and Kumar Akash (2011): "An Exploratory Study of Factors Affecting Selection of Life Insurance Products", Insurance Theory and Practice, Prentice Hall of India Pvt. Ltd, New Delhi, pp. 72-81.

[8] Yadav Rajesh K. \& Mohania Sarvesh (2013), "Claim Settlement of life insurance policies in insurance services with special reference to life insurance corporation of India" Indian Journal of Economics and Development, 1(1): 29-37.

[9] Rajesh K. Yadav, Nishant Dabhade, International Letters of Social and Humanistic Sciences 7 (2013) 1-22.

[10] Rajesh K. Yadav, Nishant Dabhade, International Letters of Social and Humanistic Sciences 8 (2013) 77-85.

[11] Rajesh K. Yadav, Nishant Dabhade, International Letters of Social and Humanistic Sciences 5 (2014) 44-62.

[12] Rajesh K. Yadav, International Letters of Social and Humanistic Sciences 10(2) (2014) 84-90.

[13] Rajesh K. Yadav, Nishant Dabhade, International Letters of Social and Humanistic Sciences 10(2) (2014) 181-201. 